
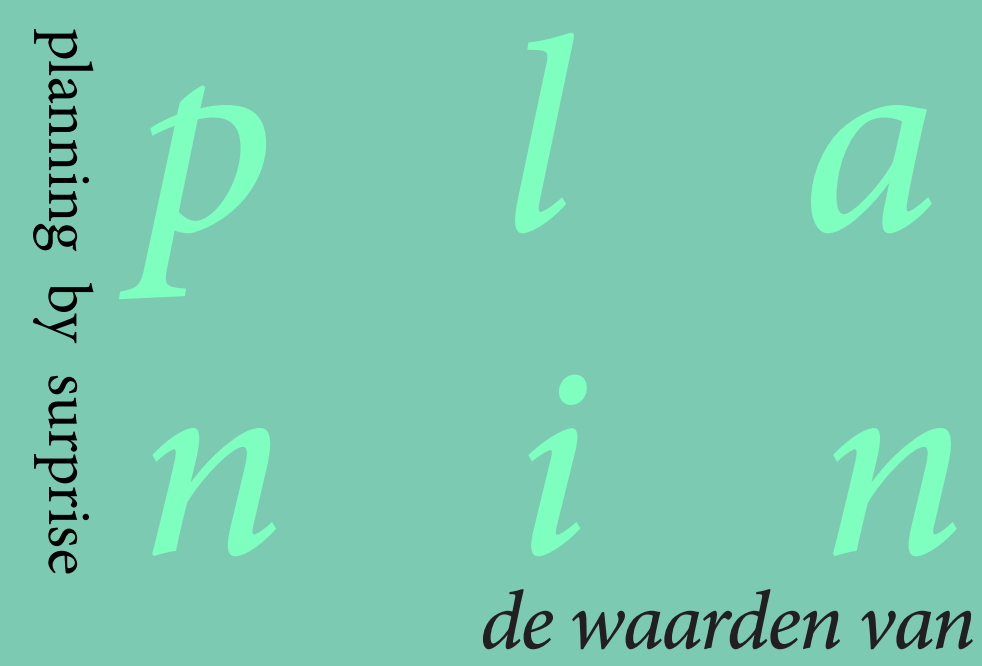

de groene ruimte in de stad

WIM TIMMERMANS

JUANEE CILLIERS

JIMMIE SLIJKHUIS

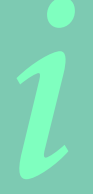



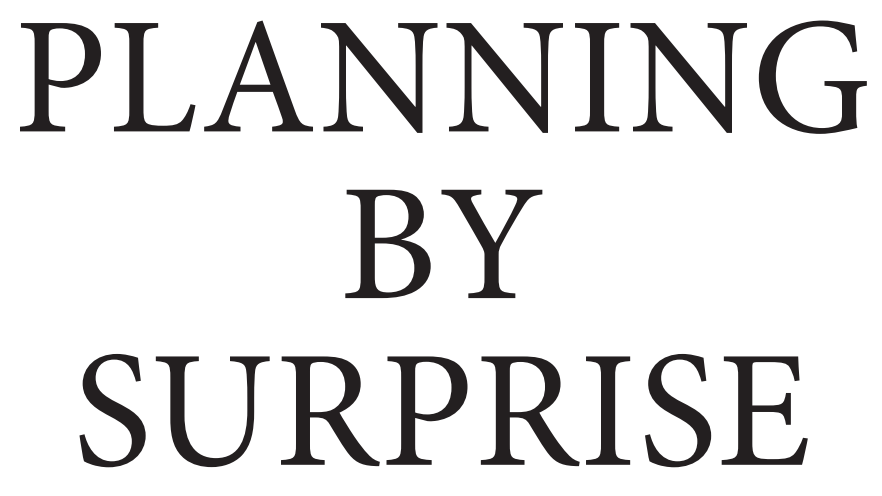

\section{de waarden van de groene stad}

Wim Timmermans

Juanee Cilliers

Jimmie Slijkhuis 
PLANNING BY SURPRISE,

DE WAARDEN VAN DE GROENE STAD

Auteurs

Wim Timmermans

Juanee Cilliers

Jimmie Slijkhuis

REDACTIE

Martin Woestenburg

VORMGEVING

Jos Jonkhof / Jonkhof Onderzoek\&Services

Letter: Cambria, Minion, Copperplate, Palatino

FOTO KATERN

Beeldredactie Jos Jonkhof

Fotos Jos Jonkhof, 6 foto's Peter Visschedijk

\section{DRUK}

Druk . Tan Heck, Delft

Papier: Munken Pure Rough 120gr. (tekst) - Satimat Green 150gr. (foto's)

\section{ISBN}

978-90-6824-035-1

\section{DOI}

\subsection{5/2018.11}

Een publicatie van het lectoraat Groene Leefomgeving - Hogeschool Van Hall Larenstein Velp, en het project VALue.

VALUE stands for 'Valuing Attractive Landscapes in the Urban Economy' and is a project funded through the European Union Interreg IVB programme for North West Europe. http://www.value-landscapes.eu/
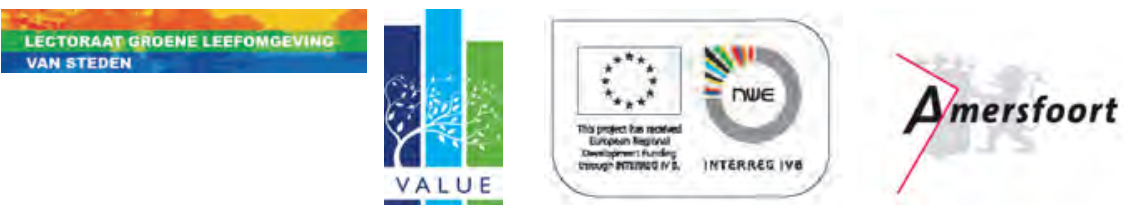
Deze publicatie is een weerslag van de experimenten die binnen VALue door Hogeschool Van Hall Larenstein zijn uitgevoerd.

De publicatie bestaat uit drie delen. De eerste twee hoofdstukken staan in het teken van de praktijk van de experimenten in Amersfoort en van de input en werkwijze van de studenten.

Daarna volgt een intermezzo met inspiratie uit het buitenland en voorbeelden hoe groen een impuls geeft aan de stad. De laatste twee hoofdstukken gaan over de vormgeving van zo'n groene strategie in gemeenten in Nederland.

In hoofdstuk 5 staat hoe gemeenten de meerwaarde van groen kunnen gebruiken voor nieuwe investeringen: value capturing.

In hoofdstuk 6 staat een nieuwe vorm van planning centraal: Planning by Surprise, waarin droom en pragmatisme worden verenigd.

In het centraal geplaatste foto essay, wordt het verhaal verteld van de vele kanten van de groene stad. Onbedoeld, bedoeld, gepland, gedroomd, getekend, herinnerd, verbeeld, ontstaan: Planning by Surprise.

de auteurs 
Levert groen geld op?

Leren van experimenten

Planningsinstrumenten

Hoe meet je groen in de stad?

Wat willen de bewoners?

Hoe vang je de waarde van groen?

Experimenten

2 DE PRAKTIJK: AMERSFOORT

15

Park Randenbroek past in groene strategie

Value Added Planning

Meer kwaliteit voor Euterpeplein

Green Credit Tool

Timing is belangrijk

Gelijktijdig tekenen en rekenen

3 STUDENTENWORKSHOP IS HOGEDRUKPAN

Fietsen

Context

Biertjes en discussie

4 BUITENLAND: HOE GROEN DE STAD VERANDERT ALS KATALYSATOR VOOR STEDELIJKE ECONOMIE

Parken worden centrum van buurtleven

Buurtuin voor voedsel

10 jaar lang experimenteren

Geen copy paste

5 OOGSTEN WAT GEZAAID IS

Value capturing

Tegelijk afromen en investeren

Omdenken over financiën en planning

6 PLANNING BY SURPRISE: GROEN AGENDEERT

Technische en communicatieve planning

Toeval en verrassing

Gevoelens, indrukken, toevalligheden, persoonlijke relaties, politieke veranderingen

Afhankelijk van zachte informatie

Geloof en pragmatisme

Planning by surprise 


\section{INLEIDING}

Groen zorgt voor een gezonde, leefbare, rendabele, schone en mooie stad, maar is ook economisch interessant voor de stad als vestigingsklimaat van bedrijven. In het Europese project VAlue (Valuing Attractive Landscapes in the Urban Economy) hebben tien partners ${ }^{1}$ van 2008 tot 2012 samengewerkt om bewijs te verzamelen van de economische meerwaarde die groen heeft voor steden.

Dat groen belangrijk is voor de stad is gemeengoed. Gemeenten dingen met enthousiasme mee naar de titel 'Groenste stad', makelaars prijzen de groene woonomgeving, parken worden steeds vaker louncheplekken en jog-routes, projectontwikkelaars gebruiken groen als verkoopargument, en er is steeds meer wetenschappelijk bewijs dat groen goed is voor de gezondheid, het leefmilieu en het stadsklimaat.

1. Sheffield City Council, de gemeente Amersfoort, Vlaamse Landmaatschappij, Hogeschool Van Hall Larenstein, University of Sheffield, Verband Region Stuttgart, Services Promotion Initiatives en province de Liège, Université de Liège, Institut für Landes- und Stadtentwicklungsforschung und Bauwesen des Landes Nordrhein-Westfalen en Community Forest North West.
Dat besef is ook ontstaan dankzij de enorme groei die steden in de afgelopen vijftig jaar doormaakten. Daarmee maakte groen plaats voor gebouwen en infrastructuur. Voormalige groene ruimten werden steeds meer opgevuld door woningen, infrastructuur, bedrijven-terreinen en andere voorzieningen, met allerlei negatieve effecten van dien. Dit riep verzet op, een defensieve reactie die paste bij het groeiende milieubewustzijn aan het eind van de twintigste eeuw. Groen word nu belangrijk gevonden. De stad kan niet zonder. 


\section{LEVERT GROEN GELD OP?}

In de afgelopen tien jaar is de economische meerwaarde van het groen belangrijker geworden, een proces dat met de economische crisis is versterkt. Steden met veel, mooi en functioneel groen zijn namelijk vaak ook de steden zijn die aantrekkelijk zijn om te wonen, werken en recreëren. Groen zorgt dus voor een prettig leefklimaat, en dat maakt groen economisch en financieel interessant omdat het de concurrentiepositie van een stad versterkt.

Voor een gemeentelijke overheid is investeren in groen daarom niet alleen aantrekkelijk vanwege het voorkomen van negatieve effecten, maar vooral vanwege de economische positie van de stad in het stedelijke netwerk van de regio, het land en Europa. De grote vraag is echter of een investering in stadsgroen ook daadwerkelijk iets oplevert. Het probleem is namelijk dat de meerwaarde van het stadsgroen maar moeilijk in geld uit te drukken valt. Er zijn wetenschappelijke bewijzen dat groen bijdraagt aan de gezondheid, dat het een beter milieu oplevert, mensen samenbrengt, en woningen meer waard maakt. Maar wie profiteert daarvan? En hoe kun je dat op een goede manier kunt organiseren? Dat waren de vragen die centraal stonden binnen Value.

\section{LEREN VAN EXPERIMENTEN}

Binnen VALUE werkten de afgelopen jaren onderzoeksinstellingen en de gemeenten samen aan de ontwikkeling van methoden om groen in geld uit te drukken, om bewoners bij deze waardering van het groen te betrekken, en om te onderzoeken welke strategieën de gemeenten kunnen ontwikkelen om te 
zorgen dat de stad als geheel profiteert van de meerwaarde. Doel van de Europese samenwerking was dat de gemeenten van elkaars experimenten leerden, en dat bestuurders leren samenwerken en profiteren van elkaars kennis en ervaring. In het grotere geheel gaat VALUE over het ontwikkelen van groene strategieën voor steden en regio's. Het onderzoek van VALUE was gericht op de vraag waar het investeren in groene infrastructuur in steden en regio's de maximale economische winst oplevert, en hoe die groene infrastructuur tegelijkertijd bijdraagt aan een goede ruimtelijke kwaliteit van die steden en regio's. Dit onderzoek werd gedaan vanuit het idee dat groene infrastructuur van vitaal belang is voor de kracht en welvaart van steden in Noordwest-Europa. Met het onderzoek werd bewustzijn gecreëerd voor de waarde van groen.

\section{PLANNINGSINSTRUMENTEN}

In deze publicatie ligt de nadruk op de Nederlandse samenwerking tussen Hogeschool Van Hall Larenstein en de gemeente Amersfoort. Onderzoekers en studenten van de hogeschool onderzochten planningsmethoden over de economische meerwaarde van het stadsgroen. Die zijn vervolgens samen met de gemeente Amersfoort in diverse experimenten in de praktijk gebracht rond het groen van Euterpeplein, Park Randenbroek en de wijk Vathorst. 
Binnen VALuE is gericht ingezet op drie planningsinstrumenten die voor groene strategieën kunnen worden ingezet:

- de Green Credit Tool om te onderzoeken welke waarde groen heeft

- de Workbench Spatial Quality om bewoners, gebruikers en belangengroepen bij de planning te betrekken

- Value Added Planning om de meerwaarde van groen economisch en maatschappelijk te maximaliseren

\section{HOE MEET JE GROEN IN DE STAD?}

Om te bepalen wat de economische meerwaarde van het stadsgroen is het logisch om eerst te kijken naar het groen dat in de stad aanwezig is. Daarvoor werd de Green Credit Tool ingezet. Even logisch is het om daarna te kijken wat de Amersfoorters vinden van dat stadsgroen. Hiervoor werd de Workbench Spatial Quality gebruikt. De vervolgvraag hoe de gemeente Amersfoort de economische meerwaarde kan gebruiken voor beleid en planning, werd onderzocht via de methode van Value Added Planning.

De Green Credit Tool is een methode om de waarde van groen te meten in een stad. De methode is door de gemeente Amersfoort ontwikkeld, en binnen Value in verschillende pilots getest. De methode komt voort uit het idee van natuurcompensatie, waarbij verlies aan natuur door nieuwe ruimtelijke ontwikkelingen kan worden gecompenseerd via aanleg en verbetering van groen of via financiële compensatie. Dit natuurcompensatiebeginsel komt voort uit Europese natuurwetgeving, en is ook opgenomen in Nederlandse wetgeving. Hiermee heeft de Green Credit Tool een wettelijke basis. 
Via de Green Credit Tool kan men het stadsgroen op zeven aspecten beoordelen: op het gebruik, via de perceptie, qua water en ecologie, cultureel en architectonisch, op de stand van beheer en onderhoud, op het landgebruik, en op de waarde van het gebied. Deze kwaliteitsaspecten van het groen in de stad worden vervolgens in een matrix uitgesplitst naar diverse deelaspecten die relevant zijn voor de vele doelgroepen binnen de stad. Dit maakt de Green Credit Tool een geschikte methode om het gesprek aan te gaan met buurtbewoners en andere belanghebbenden over de gevolgen van bijvoorbeeld de aanleg van een weg, nieuwe huizen, of de herinrichting van het stadsgroen.

\section{WAT WILLEN DE BEWONERS?}

De Workbench Spatial Quality is eigenlijk een verzameling van methoden voor participatie die gebruikt wordt om de meerwaarde van stadsgroen vast te stellen. Het is ontwikkeld door Habiforum. De methode is opgedeeld in vier fases die in een cirkel op elkaar aansluiten. De eerste stap bestaat vaak uit een excursie door het gebied, om de beleving van alle betrokkenen vast te leggen. Iedereen is hierbij een expert. Daarna wordt samen een kwaliteitsprofiel gemaakt van het gebied, waarin mensen punten geven voor de gebruikswaarde, de belevingswaarde en de toekomstige waarde. In de derde fase ontwikkelen mensen via scenario's, calculaties, mapping en de lagenbenadering een plan voor het gebied.

Fase vier gaat over het ontwerp en de realisatie. Het resultaat wordt gemonitord, onder meer op opnieuw de beleving van alle betrokkenen. 
HOE VANG JE DE WAARDE VAN GROEN?

Via Value Added Planning kunnen gemeenten onderzoeken hoe investeringen in groene infrastructuur ook een meerwaarde kunnen opleveren voor de rest van de stad. Uitgangspunt is hierbij het harde gegeven dat woningen in een groene omgeving tussen de vijf en vijftien procent meer waard zijn. De grote vraag hierbij is hoe gemeenten die investeren in een groene woonomgeving, van die meerwaarde kunnen profiteren.

Value Added Planning begint helemaal in het begin van het planningsproces, namelijk met de vraag of groen feitelijk een meerwaarde oplevert en of er in de woningmarkt ruimte is om daarmee te verdienen. Uit de praktijk van Amersfoort komen diverse mogelijkheden naar voren. Een specifiek groen ontwerp kan bijvoorbeeld economisch een meerwaarde opleveren. Via modellering kan een gemeente de meerwaarde van groeninvesteringen strategisch inzetten. Gemeenten kunnen via samenwerking met publieke en private partijen strategieën ontwikkelen om mee te profiteren van de meerwaarde van huizen in groene woonmilieus. Ook is gekeken wat groen betekent voor de toekomstige ruimtelijke planning van Amersfoort.

\section{EXPERIMENTEN}

Deze publicatie is een weerslag van de experimenten die binnen VAlue door Hogeschool Van Hall Larenstein zijn uitgevoerd. De publicatie bestaat eigenlijk uit drie delen. De eerste twee hoofdstukken staan in het teken van de praktijk van de experimenten in Amersfoort, en welke input en werkwijze de 
studenten daarin hebben gehad. Daarna volgt een intermezzo met inspiratie uit het buitenland en voorbeelden hoe groen een impuls geeft aan de stad. De laatste twee hoofdstukken gaan over de manier waarop zo'n groene strategie in gemeenten in Nederland kan worden vormgegeven. In hoofdstuk 5 staat hoe de gemeenten de meerwaarde van groen kunnen gebruiken voor nieuwe investeringen via value capturing. In hoofdstuk 6 staat een nieuwe vorm van planning centraal: Planning by Surprise, waarin droom en pragmatisme worden verenigd. 


$$
\theta
$$




\section{DE PRAKTIJK: AMERSFOORT}

Park Randenbroek en het Euterpeplein zijn de twee gebieden waar mensen van de gemeente Amersfoort met onderzoekers en studenten van Hogeschool Van Hall Larenstein experimenten hebben uitgevoerd om te kijken hoe je de economische meerwaarde van groene infrastructuur kunt maximaliseren. Hieruit bleek dat er gezocht moet worden naar manieren om het tekenen van het ontwerp en het berekenen van de investeringen en waarden te combineren. Daarbij moet het planningsproces centraal staan.

De inbreng van bewoners, gebruikers en belangengroepen stond voor de gemeente Amersfoort bij beide projecten vanaf het begin centraal. Voor de groene strategie rond Park Randenbroek was de gemeente al van plan om met Value Added Planning de meerwaarde van dat groen economisch te maximaliseren. Ook was een publieksconsultatie via de Workbench Spatial Quality voorzien. Bij het Euterpeplein wilde de gemeente via de Green Credit Tool samen met bewoners, gebruikers en belangengroepen de waarde van het gebied en het groen in kaart brengen. Dit alles werd als onderdeel ingebracht in het Europese project VALUE. In samenwerking met Hogeschool Larenstein werd de theorie van de drie planningsinstrumenten, zoals uiteengezet in hoofdstuk 1, getest in de praktijk van de gemeente Amersfoort. 
PARK RANDENBROEK PAST IN GROENE STRATEGIE

Park Randenbroek springt er op de satellietfoto duidelijk uit als een van de grote groengebieden in Amersfoort. Het park is een overblijfsel van een zeventiende eeuws landgoed, met daaromheen sportvelden en het Sint Elisabeth Ziekenhuis. Het maakt deel van de beekvallei van de Heiligenbergerbeek die van het zuiden de stad in loopt. Langs de beek liggen diverse sportvelden en een ziekenhuis.

Door het vertrek van het ziekenhuis en een tennisclub en de wens van diverse sportclubs voor meer ruimte en nieuwe faciliteiten, werd het vanaf het jaar 2000 nodig om te kijken naar de herontwikkeling van het park. Voor de gemeente Amersfoort lagen er twee opgaven, namelijk de ontwikkeling van een groen recreatiegebied door het beekdal en de herontwikkeling van de gebouwen van het ziekenhuis.

Er is steeds gekozen om een complete groene strategie te ontwikkelen voor het hele gebied van Park Randenbroek tot aan de A28. Bij de herontwikkeling van het gebied van het ziekenhuis Sint Elisabeth was het uitgangspunt dat de nieuwbouw van het nieuwe ziekenhuis Meander Medisch Centrum en de verhuizing van het Sint Elisabeth-ziekenhuis en het Lichtenberg-ziekenhuis zonder extra kosten plaats zou vinden.

Concreet betekende dat het ontwikkelen van plannen voor woningbouw op de Elisabeth-locatie. In deze plannen werd rekening gehouden met zoveel mogelijk groene ruimte langs de beek. 
Value Added Planning

De toepassing van Value Added Planning begon voor de gemeente Amersfoort eigenlijk al vanaf het begin van de planvorming voor Park Randenbroek in 2000. Daarbij bleek al snel dat de politieke besluitvorming enorm belangrijk is. Aanvankelijk was het idee om het oude Sint Elisabeth Ziekenhuis door een woningcorporatie om te herontwikkelen tot appartementen, waarbij het nieuwe 'rood' geld zou opleveren voor de groene ontwikkeling. Dat veranderde in 2010, toen het nieuw verkozen college van burgemeesters en wethouders besloot om ook van het ziekenhuisterrein een park te maken. Zo ontstond een plan voor een 65 hectare groot groengebied, een groene long voor Amersfoort.

De Workbench Spatial Quality werd bij Park Randenbroek ingezet om naast ecologische en cultuurhistorische belangen ook economische belangen en waarderingen in beeld te brengen. De groene herontwikkeling van Park Randenbroek werd zo onderdeel van de fundamentele discussie over de groene strategie van de gemeente, met veel belangen en veel belanghebbenden.

\section{MEER KWALITEIT VOOR EUTERPEPLEIN}

Bij het Euterpeplein kwam de gemeente voor een opgave van een geheel andere orde te staan. Het Euterpeplein is een driehoekig plein in de naoorlogse wijk Schuilenburg. Tussen enkele drukke wegen lag daar een parkeerplaats voor auto's, omgeven door bomen met rondom winkels en huizen. De ruimtelijke kwaliteit was laag, en de bomen op het plein waren niet of nauwelijks levensvatbaar. 
Dat moest beter, besloot de gemeente. De ambitie was om waarde van het groen te verhogen: de esthetische kwaliteit, de gebruikskwaliteit, de natuurlijke kwaliteit, de culturele kwaliteit en de beheerskwaliteit. Om te controleren of dit ook werkelijk gebeurde, zette de gemeente de Green Credit Tool in. Dat instrument gebruikt de gemeente op kleinere gebieden om antwoord te krijgen op de vraag of het groen behouden, vervangen, verplaatst dan wel weggehaald kan worden. Onderzoekers en studenten van Hogeschool Larenstein begeleidden de inzet van de Green Credit Tool.

\section{GREEN CREDIT TOOL}

De Green Credit Tool sloot aan op het zeven stappen durende proces van burgerparticipatie, dat door de gemeente werd gebruikt voor de wijk Schuilenberg. Dat begon met gesprekken met bekende stakeholders, en ging verder via het luisteren en contacten leggen, het gesprek aangaan met de bewoners om verdieping te zoeken, bewoners meenemen in het planproces, discussies over hoe het verder moet, de formele inspraak, en als laatste een rondrit door de wijk met een oude bus en een videocamera om de reacties vast te leggen.

Het instrument werd in dit proces gebruikt om de waarde van het plein in beeld te brengen en een afweging te kunnen maken van het in overleg gemaakte ontwerp. Dit gebeurde in samenwerking met bewoners, bedrijven en organisaties uit de buurt. Deze groep werd schriftelijk gevraagd om vragen te beantwoorden over het huidige groen en de wensen ten aanzien van het toekomstige groen. De verschillende kwaliteitsaspecten (het gebruik, de perceptie, water en ecologie, 
cultureel en architectonisch, de stand van beheer en onderhoud, het landgebruik en de waarde van het gebied) werden vervolgens in een matrix uitgewerkt. Met die matrix kon vervolgens worden berekend wat de kwaliteit van het toekomstige groen zou zijn voor de bewoners, bedrijven en organisaties in de buurt.

De conclusie luidde dat de nieuwe plannen voor het Euterpeplein op zijn minst een gelijkwaardige groene kwaliteit zou opleveren en misschien wel een positief effect kon hebben. Tijdens het proces bleek dat de respons op de schriftelijke vragenlijst beperkt was. Verder bleek dat het voor bewoners moeilijk was om objectief te zijn over bomen. Het verwijderen van de oude bomen lag bijvoorbeeld gevoelig, ook al kwamen er nieuwe bomen die op de lange duur voor betere ruimtelijke kwaliteit zorgde. Dit subjectieve perspectief zorgde dat mensen moeilijk onbevooroordeeld konden kijken naar de toekomstige kwaliteiten van het groen.

\section{TIMING IS BELANGRIJK}

Het is belangrijk is om de beleidsinstrumenten als Value Added Planning, Workbench Spatial Quality en Green Credit Tool op het juiste moment in te zetten. Timing is belangrijk, en het blijkt dat je beter eerder dan later aan de slag kan. Achteraf gezien is bijvoorbeeld duidelijk dat de Workbench Spatial Quality eerder had moeten worden ingezet. Dan waren er in de planning meer mogelijkheden geweest, en waren bewoners, gebruikers en belangenpartijen eerder meegegaan in de besluitvorming rondom de finale planvorming. 
Ook de Green Credit Tool werd bij het Euterpeplein te laat ingezet, nadat het ontwerp gemaakt was. Achteraf was het beter geweest om het vroeger in de ontwerpfase in te zetten, omdat de resultaten van het onderzoek beter meegenomen konden worden in het ontwerp van het groen. Als de Green Credit Tool niet vanaf het begin wordt gebruikt, dan wordt het een instrument om keuzes die al zijn gemaakt te verdedigen of uit te leggen. Om de mensen er beter bij te betrekken, is het ook aan te bevelen om op te passen met jargon en terminologie waar die mensen niet mee vertrouwd zijn. De vragenlijst moet dus aansluiten bij de leefwereld van de mensen waarop die is gericht.

\section{GELIJKTIJDIG TEKENEN EN REKENEN}

De praktijk leert dat het berekenen van een directe meerwaarde van de vergroening van Park Randenbroek en de vergroening van het ziekenhuisterrein erg moeilijk ligt. Die meerwaarde is namelijk niet direct gerelateerd aan het gebied waar de ontwikkelingen plaatsvinden, maar vooral afhankelijk van wat er in de grotere context gebeurt. De meerwaarde van groen blijkt niet alleen afhankelijk van de lokale, politieke, bestuurlijke en economische omstandigheden, maar ook van bredere, nationale ontwikkelingen op de woningmarkt en in de economie.

Bij Value Added Planning wordt gelijktijdig getekend en gerekend om die ruimtelijke kwaliteit te vinden, die de hoogste economische meerwaarde oplevert. Zo kan de gemeente inzetten op een indirecte manier van zoeken naar een economische meerwaarde. Omdat bewoners, gebruikers en belan- 
genpartijen zelf de partij zijn die het meest profiteren van de ontwikkeling van het nieuwe park, lijkt het een logische zet om die mensen ook mee te laten doen in de zoektocht naar de economische meerwaarde van de groene ontwikkeling. Het planningsproces moet centraal staan, niet de directe opbrengsten van dat proces. Dat was de belangrijkste conclusie die de gemeente Amersfoort trok ten aanzien van de inzet van Value Added Planning. Directe, economische opbrengsten van groene infrastructuur zijn moeilijk te berekenen, maar er is wel meerwaarde mogelijk door vanaf het begin van de planvorming verschillende disciplines te laten samenwerken.

Ontwerpers tekenen, planeconomen rekenen. Dit gebeurt in meer projecten, maar niet tegelijkertijd. Vaak wordt eerst getekend vanuit ruimtelijke kwaliteit en daarna gerekend op inrichtingskosten. Terwijl het gaat om het combineren van rekenen en tekenen in een multidisciplinair planningsproces. Dit sluit aan bij de ervaringen in de studentenworkshop in het volgende hoofdstuk. 


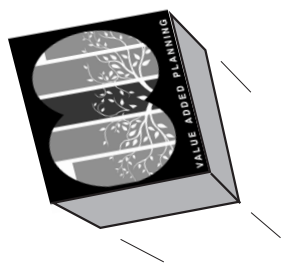

22 


\section{STUDENTENWORKSHOP IS HOGEDRUKPAN}

Het is een beproefde methode van Hogeschool Van Hall Larenstein om studenten uit diverse disciplines een aantal dagen bijeen te brengen om als het ware in een hogedrukpan nieuwe plannen te maken voor bestaande ruimtelijke opgaven. Zo verbleven achttien studenten in oktober 2011 in het Stayokay in Soest om onderzoek te doen naar Park Randenbroek in Amersfoort. Studenten stedenbouw en verkeerskunde van Saxion, studenten landschapsarchitectuur en planning van Van Hall Larenstein en studenten vastgoed van Hanze Hogeschool Groningen bogen zich over de vraag hoe je bij Park Randenbroek toegevoegde waarde creëert met behulp van groene infrastructuur.

De studentenworkshops van Hogeschool Van Hall Larenstein bestaan uit een afwisselend programma met lezingen, excursies, ontwerpsessies, prikkelende statements van buitenstaanders en veel discussie, wat resulteert in een presentatie aan de opdrachtgever. De gemeente Amersfoort was in dit geval de opdrachtgever van de studenten voor Park Randenbroek. Docent Ad Koolen begeleidde de studenten, in samenwerking met Arno Goossens van de gemeente.

\section{FIETSEN}

De workshop begon op woensdag 21 oktober met een inleiding van de Arno Goossens over de manier waarop Park Randenbroek past in de structuurvisie van de gemeente. Het herstel van het park past bij het verbeteren van de Heiligenbergerbeek als drager van ecologie en recreatie en het maken 
van groene verbindingen. Na de inleiding fietsten de studenten met Goossens langs de drie deelgebieden: het zwembad in het noorden dat plaats maakt voor groen en stadsvilla's, het ziekenhuis in het midden dat verdwijnt en waar twee groengebieden worden ontwikkeld, en de plek ten zuidoosten van de beek waar een nieuwe woonwijk zal komen. Zes multidisciplinaire groepjes studenten werden samengesteld om de drie gebieden te bestuderen. Woensdagavond kregen de studenten lezingen van vastgoedexpert Jan Bervaes en planoloog Terry van Dijk van Alterra. Deze externe deskundigen vertelden beiden vanuit hun eigen perspectief het verhaal over de relatie tussen het rood en het groen van een stad. Dat leverde een tegenstrijdig beeld op. Bervaes vertelde dat woningen met water aan de achterkant tien procent in prijs stijgen, maar dat water aan de voorkant nauwelijks invloed heeft. Ook hebben mensen behoefte aan een wandelrondje in de directe woonomgeving. Die is er bijna niet. Van Dijk was als planoloog sceptisch over het verzilveren van de meerwaarde van groene woningen, want innen dat is volgens hem duur en juridisch moeilijk.

\section{CONTEXT}

Donderdag was de dag van de ontwerpsessie. De zes groepen studenten zetten hun ideeën op papier, de eerste schetsen ontstonden. Opvallend was dat menig groepje naar context zocht. Aangrenzend werkende groepjes kwamen veel bij elkaar kijken en discussiëren. Er waren ook grote verschillen in de manier van denken. Studenten landschapsarchitectuur dachten eerder aan de mogelijkheden in het gebied, terwijl de 
planologen de haalbaarheid voorop stelden. De groepjes vonden ruimtelijk wel overeenkomsten in de drie deelgebieden: bij het zwembad was het landhuis belangrijk, bij het ziekenhuis bleek de Heiligenbergerbeek de verbindende hoofdlijn, en bij de nieuwe woonwijk stelde iedereen groen verbinden als voorwaarde.

In de avond kregen de studenten opnieuw voeding van twee experts van buiten: lector vastgoed Frank van Genne van Hogeschool Saxion en landschapsarchitect Rüdiger Amend van bureau LA.BAR uit Berlijn. Van Genne stelde dat je kunt voorspellen hoe mensen reageren op een woonomgeving, en of ze er willen wonen. "Mensen maken keuzes, zodat ze kunnen laten zien wie ze zijn en waar ze bij horen." Daarom is het belangrijk om na te denken welke doelgroep je met een ontwerp wilt benaderen. Amend vertelde over zijn ervaringen in Berlijn met Value Added Planning, de methode die ook de gemeente Amersfoort gebruikte om meerwaarde van groen te realiseren. Hij wees op het gebruik van tijdelijk niet gebruikte, braakliggende terreinen door bewoners, bijvoorbeeld als moestuin. Dat leverde in Berlijn discussies op of zulke plekken niet permanent onbebouwd moeten blijven.

\section{BIERTJES EN DISCUSSIE}

Daarna bleek de meerwaarde van de hogedrukpan. De landschapsarchitecten waren in eerste instantie leidend in het ontwerp. Vastgoed-studenten volgden daarbij kritisch hoe de ontwerpers op geheel eigen wijze invulling gaven aan de meerwaarde van het groen in de stad. Na een biertje en wijntje of wat ontstonden 's avonds heftige discussies. Daarin wis- 
ten de vastgoed-studenten duidelijk te maken wat hun meerwaarde was in het geheel: zij kunnen rekenen bij het tekenen van de ontwerpers.

De discussie op donderdagavond gaf de groepjes studenten een nieuwe, frisse blik op de opgaven, maar ook een nieuwe werkverhouding. In de laatste ontwerpsessie concentreerden de groepjes zich allereerst op de financiële onderbouwing, met gepuzzel over de hoeveelheid huizen, de kosten van het slopen, en waar nieuwbouw geplaatst moet worden om financieel zo goed mogelijk uit te komen. Internet en eigen bestanden werden afgezocht voor geschikte referentiebeelden. Er ontstond ook een duidelijke taakverdeling in de groepjes: landschapsarchitecten tekenden voor het ontwerp, vastgoedstudenten rekenden aan de meerwaarde van groen, en taken werden zo efficiënt mogelijk verdeeld.

Zo keken de groepjes studenten eensgezind naar waar, maar vooral waarom ze ergens iets wilden ontwikkelen. Door de nieuwe manier van samenwerken ontstond een betere onderbouwing van het verhaal en een duidelijker concept. De studenten werkten tot laat in de avond door om de presentatie van de volgende dag goed voor te bereiden.

Zaterdag ontspon zich na de presentatie over de drie deelgebieden een discussie met de mensen van de gemeente Amersfoort. Die waren blij verrast met de hoeveelheid werk die in zo'n korte tijd was verzet. 


\section{BUITENLAND: HOE GROEN DE STAD VERANDERT ALS KATALYSATOR VOOR STEDELIJKE ECONOMIE}

In het buitenland zijn goede voorbeelden te vinden van hoe groen nieuw leven kan blazen in het stedelijk weefsel. Drie voorbeelden uit Frankrijk en Duitsland laten hier zien hoe de stad in beweging komt na investeringen in groene infrastructuur. Kanttekening: de voorbeelden zijn niet één op één te kopiëren naar Nederland. Er is geen simpel recept via copy paste. Gemeenten zullen in Nederland hun eigen groene planning moeten uitvinden, waarbij zij zelf moeten uitrekenen wat de meerwaarde van het groen is, met de instrumenten en planningsmogelijkheden die in deze publicatie worden beschreven.

\section{PARKEN WORDEN CENTRUM VAN BUURTLEVEN}

De Promenade Plantée is van oorsprong een viaduct voor het smalspoor van de Place de la Bastille naar het Bois de Vincennes. Dat functioneerde van de negentiende eeuw tot het in1969 definitief werd gesloten. Toen in 1984 het station Bastille werd gesloopt om plaats te maken voor de nieuwe Opéra Bastille kwam er ook geld voor de aanleg van de Promenade Plantée. Arcades werden gerenoveerd, en bestaande taluds, spoorviaducten, bijgebouwen en tunnels werden geintegreerd in de promenade. In 1993 lag er een bijna vijf kilometer lange groene promenade met een breedte van negen tot dertig meter. Die liep van het tien meter hoge Viaduc des Arts met kunstwinkels bij de Place de la Bastille tot het bij de Jardin de Reuilly vlakbij Rue Montgallet weer op de grond terecht komt. 
Maar toen begon het pas. De gebouwen stonden in het begin als het ware met de rug naar het spoorviaduct, zonder ramen om het geluid en het stof buiten te houden. De Promenade Plantée zorgde ervoor dat die gebouwen zich als het ware omkeerden. Dankzij het groen kwamen er ramen en balkons, en appartementen met uitzicht op het groen. Het spoorviaduct werd zo het groene hart van de buurten eromheen. Woningen werden meer waard, de buurten werden aantrekkelijker om in te wonen en te werken, en er ontstond nieuwe bedrijvigheid.

Sindsdien is het concept van de Promenade Plantée succesvol ingezet in New York bij de herontwikkeling van de High Line, met als prominente herontwikkeling het nieuwe Standard Hotel bovenop het viaduct. Het succes van de Promenade Plantée en de High Line heeft steden als Chicago, Philadelphia en Saint Louis aangezet tot plannen voor het vergroenen van voormalige spoorlijnen. In Rotterdam zijn er plannen voor de Hofbogen op het viaduct van de voormalige Hofpleinlijn. Zulke projecten worden gezien als katalysator van het stedelijk leven en als belangrijke impuls voor de economie van de buurten eromheen.

\section{BUURTUIN, MEER LUCHT IN RUIMTE EN TIJD}

Van een andere ordegrootte zijn de Jardins Partagés, tijdelijke tuinen, moestuinen en parkjes die ontstaan op plekken waar er even een rustpauze is in de doorlopende bouwnijverheid in de stad. Dit is een gebruik dat in de negentiende eeuw ontstaat in Frankrijk, 'arbeiderstuinen' en 'werktuinen' werden aangelegd om het volk van voedsel te voorzien. 
Het is een simpel idee. In de stad zijn er regelmatig locaties beschikbaar waar tijdelijk niet gebouwd wordt. De gemeente helpt de bewoners met voorlichting, materiaal en toezicht voor de aanleg en de inrichting van de stadstuinen, en stelt samen met de bewoners een contract op waarin het tijdelijke gebruik goed geregeld wordt. Dit schept zekerheid zowel voor overheden en ontwikkelaars als voor de bewoners. Zij onderhouden en gebruiken de tuinen. Parijs heeft nu ruim veertig Jardins Partagés, en het fenomeen heeft zich verspreid over heel Frankrijk.

Het principe is aanvankelijk geïnspireerd door de Community Gardens uit New York. Daarvan zijn er nu zo'n 750. In Nederland is er in 2010 in Maastricht een eerste 'Buurtuin' aangelegd.

\section{JAAR LANG EXPERIMENTEREN}

Experimenteren vormt de basis onder het concept van de Internationale Bauausstellung (IBA) in Duitsland. Dit planningsinstrument werd voor het eerst in 1901 in Darmstadt toegepast. Bij een IBA investeren regionale overheden voor maximaal tien jaar geld in ruimtelijke experimenten die een sociale, economische, culturele en ecologische impuls moeten opleveren voor de regio. Geslaagde experimenten overleven daarna op eigen kracht.

Bekend is de IBA Emscher Park in het Ruhrgebied, van 1989 tot 1999. De mijnbouw en industrie was in dat gebied op zijn retour, en de grootschalige mijnbouw zorgde dat het natuurlijke water in het gebied wegzonk. Hier ontstond uit de samenwerking een internationale tentoonstelling over het hergebruik van industrieel erfgoed, met nieuwe bedrijvigheid uit de dienstensector en een omvorming van het industrielandschap tot een landschapspark. Het terugbrengen van het natuurlijke water was de directe fysieke aanleiding, maar in de loop van de jaren bleek dat tien jaar experimenteren ook leidde tot een economische opleving van de regio. 
De IBA-methode is een permanent rijdende trein, waarbij startende projecten telkens leren van lopende of beëindigde IBA's. De IBA in de voormalige bruinkoolmijnen van FürstPückler-Land is onlangs afgesloten, terwijl nieuwe IBA-projecten zijn gestart rondom Hamburg, Basel en Thüringen. Nederland is Parkstad Limburg bezig met de opzet van $I B A$ Parkstad, als krimpregio in een Euregionale omgeving.

\section{GEEN COPY PASTE}

Het zijn mooie voorbeelden, de Promenade Plantée, de Jardins Partagés en de IBA's. Zo mooi dat vele bestuurders, ontwerpers en onderzoekers er op bezoek zijn geweest, en dat er zelfs navolging is in Nederland. Toch is een waarschuwing op zijn plaats. De Parijse promenade en stadstuinen en de Duitse tentoonstellingen komen voort uit een totaal andere politieke en bestuurlijke situatie. In Frankrijk is er bijvoorbeeld een minister voor de stad, in Duitsland zijn het investeringen van de centrale overheid die leiden tot ruimtelijke en economische ontwikkeling.

In Nederland staat de stad alleen als het gaat om de groene infrastructuur. De rijksoverheid heeft zich nu terug getrokken uit de ruimtelijke ordening en het beleid voor natuur en landschap, maar die was in de stad al heel lang afwezig. Investeren in groene infrastructuur is altijd al een zaak geweest van de gemeenten. Rondom de stad was er lange tijd wel aandacht van de rijksoverheid, voor de rijksbufferzones, de natuurgebieden en de recreatiegebieden.

Dat is ook het belang van de instrumenten die in deze brochure worden beschreven. Inhoudelijk zijn de ideeën uit Parijs 
en Duitsland misschien wel heel geschikt voor een gemeente of een regio van samenwerkende gemeenten. Hoe dat in de praktijk wordt georganiseerd, daarover zullen de gemeenten zelf moeten nadenken. In de komende hoofdstukken wordt een eerste aanzet gegeven. 
32 


\section{OOgSTEN WAT GEZAAID IS}

Gemeenten investeren in gebiedsontwikkelingsprojecten veelal in het groen en het water rondom de bebouwing, maar oogsten zelden wat ze zaaien. De aanwezigheid van parkjes, groenstroken, open ruimte en waterpartijen rondom bebouwing zorgt dat het vastgoed meer waard is. Schattingen lopen uiteen van zes tot vijftien procent meerwaarde. Normaal wordt de meerwaarde op het vastgoed geïncasseerd door projectontwikkelaars en eigenaren van het vastgoed, en wordt die later verhandeld.

Groen is belangrijk voor de gemeenten, als onderdeel van de marketing mix die een stad een aantrekkelijke vestigingsplaats voor bedrijven en bewoners maakt, en voor het leefklimaat. Gemeenten hebben echter vaak niet de middelen om groenvoorzieningen aan te leggen en te beheren. En tot voor kort was er ook weinig aandacht voor de meerwaarde die het van overheidswege investeren in groen oplevert.

\section{VALUE CAPTURING}

Er is echter een groeiend besef dat investeringen van overheden kunnen leiden tot waardevermeerdering van vastgoed. Value capturing is een nieuwe term die uit dat besef voortkomt. Het is een verzamelnaam voor instrumenten die zorgen dat de meerwaarde van vastgoed, die ontstaan dankzij overheidsinvesteringen in groen en water, voor een deel weer terechtkomt bij de overheden die het geld hebben geïnvesteerd. 
Value capturing gaat verder dan het 'voor wat, hoort wat'principe van 'rood voor groen'-projecten. Hierbij wordt de opbrengst van vastgoedontwikkeling (rood) gebruikt om te investeren in ruimtelijke kwaliteit (groen), maar daarbij hoeft het groen niet per se een relatie te hebben met het rood. Dit lijkt eerder op een compensatie van de rode ontwikkeling door een groene investering.

\section{TEgELIJKERTIJD AFROMEN EN INVESTEREN}

Value capturing is tegelijkertijd afromen en investeren. Het gaat om het terughalen van de investeringen die de gemeente doet in groen en water die zorgen voor meerwaarde bij het vastgoed. Maar het gaat ook en vooral om die teruggehaalde financiële middelen opnieuw in te zetten voor investeringen die de waardevermeerdering hebben veroorzaakt. Hierdoor ontstaat een doorlopend proces van investeringen, met groen dat zorgt voor meerwaarde van het vastgoed, die op zijn beurt financiële middelen oplevert voor investeringen in groen, enzovoorts.

Dit is alleen mogelijk als er ook een feitelijke waardevermeerdering van het vastgoed plaatsvindt, en dat is in de praktijk in situaties met voldoende marktdruk in de woning- en vastgoedmarkt. Er zijn al instrumenten voor value capturing beschikbaar, zoals de drie instrumenten die in deze publicatie zijn besproken.

Als de gemeente daar de mogelijkheid toe heeft, kunnen zulke instrumenten verplicht worden toegepast. Zo niet, dan is op vrijwillige basis een publiek-private samenwerking mogelijk, waarbij rekening moet worden gehouden met het lange- en 
kortetermijnperspectief van partijen als projectontwikkelaars, woningcorporaties, beleggers en particuliere vastgoedeigenaren.

\section{OMDENKEN OVER FINANCIËN EN PLANNING}

Timing is belangrijk bij value capturing. Er zijn twee momenten waarop vastgoed in waarde vermeerdert, en wanneer dus de instrumenten voor value capturing kunnen worden toegepast. In de realisatiefase, bijvoorbeeld de verkoop van een woning, is de waarde van vastgoed hoger in een groene omgeving dan in een omgeving zonder groen. Tijdens de beheersfase, als het groen volgroeid is en de woning in waarde is gestegen, zitten er momenten van waardestijging voor partijen die vanuit een langetermijnperspectief werken, zoals beleggers en corporaties.

Value capturing vergt een andere manier van denken over financiën en planning. Groenvoorzieningen moeten in een vroeg stadium opgenomen worden in de planvorming, om goed te kunnen inschatten welke mogelijkheden er zijn. Daarbij moet niet gerekend worden in termen van kosten, maar eerder in termen van investeringen en waarde. Value capturing vergt dus enig omdenken, maar is in een relatief simpel vijfstappenplan toe te passen bij gebiedsontwikkeling in een gemeente (zie het schema VIJfSTAPPENPLAN). Zo kunnen de gemeenten oogsten wat ze hebben gezaaid. 
EERSTE VOORWAARDEN

+ FEITELIJKe WAARDEVERMEerdering VAstgoed

$+\quad$ VOLDOENDE DRUK OP WONINGMARKT

$+\quad$ RELATiEF KLEIN TEKort inVEsteringen

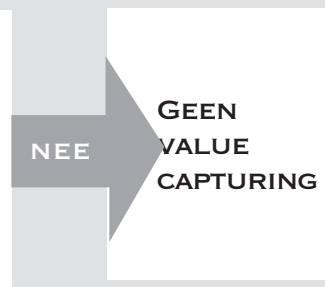

JA

WEL VALUE CAPTURING, ONDER VOORWAARDE DAT

+ GROEN EN WAARDEVERMEeRdering VROEg IN PROCES WORDT MEEgenomeN

KEUZE SAMENWERKINGSVORM

+ BOUWCLAIM: ACTIEF GRONDBELEID

+ JOINT VENTURE: WINSTDELING / ONTWIKKELAARSBIJDRAGE / OVEREENKOMST

+ Zelfrealisatie: KostenVerhaAl Via exploitatieplan

KEUZE PARTIJ MET LANGETERMIJN BETROKKENHEID:

TOTAALONTWIKKELAAR

\section{BESTAAND VASTGOED}

+ Belastingen

+ OZB / RIOOLHEFFING 


\section{PLANNING BY SURPRISE: GROEN AGENDEERT}

Ruimtelijke processen verlopen niet eenduidig of via een bepaalde regelmaat. Ze bestaan eerder uit een opeenvolging van periodes van stabiliteit en een zekere routine die af en toe worden opgeschud door een plotselinge verandering. Daarom is in VALuE gekeken hoe deze onregelmatigheden van invloed zijn op het planningsproces. Daaruit komt een nieuwe visie op planning: Planning by Surprise. Groen kan in zo'n planning de agenda bepalen.

Planningsprocessen worden over het algemeen beschouwd als een lineair traject, maar uit onderzoek binnen VALuE blijkt dat dit vaak verstoord wordt door onverwachte gebeurtenissen. Zo'n gebeurtenis wordt ook wel transitiemoment of tipping point genoemd. Op zo'n moment gebeuren allerlei dingen die zorgen dat de situatie ineens veel ingewikkelder wordt. Er ontstaan vele vraagtekens bij de periode van stabiliteit en routine, en er ontstaat een nieuw speelveld, voor een nieuwe periode van stabiliteit en routine die een hoger niveau van complexiteit heeft. Dit blijkt uit kwalitatieve interviews die binnen Value zijn gehouden met planners, bedrijven en bestuurders.

\section{TECHNISCHE EN COMMUNICATIEVE PLANNING}

Het idee dat planning een lineaire en logische ontwikkeling volgt, heeft een lange historie. In de eerste helft van de twintigste eeuw was planning de technische exercitie van het blauwdrukplan, groen was daarin grotendeels een zaak voor de cultuurtechniek. Na de Tweede Wereldoorlog paste 
dit niet meer bij de zich steeds dynamischer ontwikkelende samenleving. Er ontwikkelde zich een communicatieve planning, waarbij planning werd gezien als het resultaat van een keuzeproces van besluitvorming over bouwprojecten. Communicatie was binnen deze toelatingsplanologie de smeerolie om de besluitvorming vloeiend te laten verlopen. Groen werd één van de vele functies waarover die besluitvorming ging. Aan het einde van de twintigste eeuw ontstaat de ontwikkelingsplanologie. Die was meer gericht op het mogelijk maken van ruimtelijke ontwikkelingen en het openen van nieuwe mogelijkheden en kansen, in tegenstelling tot de gestaalde kaders waarmee de toelatingsplanologie grenzen aangaf. Communicatie speelde ook hierin een centrale rol, als smeermiddel maar ook als middel om mensen en bedrijven bij de ruimtelijke ontwikkelingen te betrekken. Groen kreeg een nieuwe rol, als een meerwaarde ten opzichte van het rood van de stedelijke ontwikkeling, zoals ook natuur, recreatie of cultuurhistorie belangrijk zijn voor de multifunctionele stedelijke ontwikkeling. Groen werd ook verkoopargument.

\section{TOEVAL EN VERRASSING}

Beide planningsopvattingen, de technische en communicatieve planning, hebben één ding gemeen: er was geen rol voor het toeval of de verrassing. Alles is gericht op berekening en sturing.

Bij de technische planning is het masterplan de blauwdruk voor de veranderingen, en zorgt onderzoek voor een feitelijke en in cijfers uit te drukken waarheid als basis voor de planning. Bij de communicatieve planning komt daarbij een 
strategische sturing op de besluitvorming, waarbij de communicatie de feiten en de waarheden aanlevert die de basis vormen voor de planning.

Ook het groen werd zo berekenend en sturend meegenomen in de planning. In de technische planning is het groen een onderdeel van de cultuurtechnische blauwdruk van de stedelijke ontwikkeling, in de communicatieve planning is groen als onderdeel in de communicatieve strategie in rekenmodellen afgezet tegenover woningbouw en infrastructuur. Telkens opnieuw werden de zachte waarden van groen - leefklimaat, milieu, ecologie, cultuurhistorie, recreatie, gezondheid, enzovoorts - in harde euro's omgerekend om in te passen in de berekenende en sturende planning.

GeVoelens, indRuKken, tOeVAlligheden, PersoonLIJKE RELATIES, POLITIEKE VERANDERINGEN

Ook het bestuur was vooral gericht op berekening en sturing. De technische en communicatieve planning gaat uit van een bestuursstijl die is gericht op efficiency. Zo'n bestuursstijl is berekenend, lineair, structureel, gebaseerd op feiten en gericht op een masterplan of een blauwdruk. Er is geen plaats voor toeval of verrassing, of voor persoonlijke zaken en emoties. In de afgelopen tien jaar zien we echter steeds vaker een adaptieve en ontwerpende bestuursstijl. Die is meer intuïtief, non-lineair, gebaseerd op ideeën en geloof, en gericht op een telkens veranderende overheid. Deze bestuursstijl is wel toegesneden op het onverwachte en onvoorspelbare. 
Er zijn dus veranderingen aan het plaatsvinden in de manier waarop planning en bestuur functioneren. Planningsprocessen blijken ook veel meer onberekenbaar en ongeleid dan in beide historische planningsopvattingen werd aangenomen. Processen zijn sterk afhankelijk van tipping points of transitiemomenten. Zo'n moment is in werkelijkheid vaak een hogedrukpan, waarin veel onverwachte dingen gebeuren. Die veranderingen zijn vaak afhankelijk van zachte informatie: gevoelens, indrukken, toevalligheden, persoonlijke relaties, politieke veranderingen, enzovoorts. Hierin speelt groen een vaak onduidelijke rol. Zie bijvoorbeeld de emotionele discussies over ontpoldering of de plaatsing van windmolenparken. Groen kan imago's en ego's maken en breken.

\section{AFHANKELIJK VAN ZACHTE INFORMATIE}

Een voorbeeld van een volstrekt onverwacht transitiemoment is het besluit van het nieuwe college van burgemeester en wethouders van de gemeente Amersfoort om het gebied rondom Park Randenbroek niet te bebouwen, maar te bestemmen als een groot groengebied. Hierbij wordt als het ware het hele planningsproces op zijn kop gezet, en beginnen alle deelnemers feitelijk helemaal vanaf het begin. Of zo'n beslissing logisch, berekenend of sturend is, is niet eens zo belangrijk, het gaat erom dat de beslissing op een onverwachte manier richting geeft aan een planningsproces.

Bestuurders zijn bij het nemen van zulke beslissingen ook vaker afhankelijk van zachte informatie. Die heeft weinig met de waarheid of de feiten van doen, in tegenstelling tot de feiten en waarheden die de basis vormen onder de technische 
en communicatieve planning. Zachte informatie is ook moeilijk te bevatten en moeilijk te vangen.

Binnen Value is getracht die zachte informatie te vatten, door diepgaande gesprekken te houden met de betrokkenen bij dit type ruimtelijk processen in Stuttgart, Amersfoort en Manchester, en daarbij te letten op de momenten en situaties die gevoelig liggen. Daaruit blijkt dat zachte informatie door mensen gekenschetst wordt in open zinnen als: "Plotseling gebeurde er..., "Toch was ik van mening..., "We zetten hen onder druk...", "Toen had ik het gevoel dat...", "Na een glas wijn bleek dat hij helemaal niet overtuigd was...", "De nieuwe wethouder echter...".

\section{GELOOF EN PRAgMATISME}

In de praktijk lopen de twee bestuursstijlen en planningsopvattingen door elkaar heen. Twee voorbeelden uit het buitenland die uit het onderzoek binnen VALue naar voren komen, illustreren dat.

In Esslingen had de gemeente een toekomststrategie gemaakt die loopt tot 2027, maar werd voor de realisatie van projecten pragmatisch gewacht op het juiste moment. In de langetermijnstrategie stond onder meer een plan voor een fietspad langs de rivier. Profiterend van het feit dat de plaatselijke voorzitter van een politieke partij ook voorzitter van de visclub was, werd de oever ontsloten via een fietspad dat ook diende als pleisterplaats voor de vissers.

Een projectontwikkelaar in Manchester hanteerde de volgende langetermijnstrategie: "We geloven in duurzame innovaties". De ontwikkelaar investeerde in duurzame energie 
als een middel om de huur laag te houden en het vastgoed aantrekkelijk. Een goed ontworpen en beheerde groene infrastructuur was voor hem vooral belangrijk omdat het waardevermindering van vastgoed kon tegengaan, niet omdat het de waarde zou vermeerderen.

Tegelijkertijd maakte het bedrijf degelijke calculaties over de maatregelen voor duurzame energievoorziening.

\section{PLANNING BY SURPRISE}

Zo wisselen bestuursstijlen en planningsopvattingen elkaar af van moment tot moment, bouwt men het geloof uit met pragmatisme en timing, en spelen lange- en kortetermijnstrategieën door elkaar. Beide bestuursstijlen blijken dus bruikbaar en effectief. Besturen op efficiency zorgt dat ruimtelijke opgaven daadwerkelijk tot nieuwe ruimtelijke ingrepen leiden, concrete resultaten die kunnen worden gebruikt om beleid en bestuur te verantwoorden.

Nieuwe groene infrastructuur is zo de reclame voor het gevoerde beleid. Adaptief en ontwerpend besturen is eerder effectief op het niveau van ideeën, visies en strategieën. Het volharden in het idee dat de economie groene infrastructuur nodig heeft, zorgt voor een gezamenlijke overtuiging en visie dat groene infrastructuur daadwerkelijk nodig is.

Planning by Surprise gaat dus niet zozeer om het maken van een plan, maar eerder om het ontwerpen van een strategie in het omgaan met verandering. In plaats van sterk te focussen op één oplossing als blauwdruk voor de ruimtelijke opgave houdt men bij Planning by Surprise de ogen open voor allerlei oplossingen die een positieve bijdrage leveren aan het 
realiseren van een langetermijnvisie. Groen heeft hierbij een agenderende functie, want het geloof in duurzaamheid of de groene visie voor de lange termijn kan op specifieke momenten via pragmatiek naadloos aansluiten bij andere economische, ruimtelijke, sociale, ecologische of andere doelen die op veel kortere termijn spelen. Daarbij zijn er harde feiten en gegevens nodig zijn om zo'n groene strategie op te bouwen met cijfers over investeringen en waarde van vastgoed en infrastructuur. Groen is dus nooit alles bepalend, maar geeft wel richting aan deelprojecten die op de korte termijn spelen. 
44 
ARTIKELEN

CILLIERS, E.J., DIEMONT, E., STOBBELAAR, D.J. \& TIMMERMANS, W. 2010. Sustainable Green Urban Planning: The Green Credit Tool. In Journal of Place Management and Development, 3(1), ISSN: 1753-8335. March 2010.

CILliERS, E.J., DIEMONT, E., STOBBELAAR, D.J. \& TIMMERMANS, W. 2010. Stakeholder behaviour in Urban Development : Evaluating the Workbench Method. In Design and desicion support systems conference proceedings, Eindhoven, The Netherlands.

CILliERS, E.J., DIEMONT, E., STOBBELAAR, D.J. \& TIMMERMANS, W. 2011. Enhancing sustainable development by means of the Workbench Method. In Environment and Planning B: Planning and Design, 38(4) 579 - 584.

CILliERS, E.J., DIEMONT, E., STOBBELAAR, D.J. \& TIMMERMANS, W. 2011. Sustainable Green Urban Planning: The Workbench Spatial Quality Method. In Journal of Place Management and Development, 4(2), 214 224. ISSN: 1753-8335. 


\section{RAPPORTEN}

CILliERS, E.J., DIEMONT, E., STOBBELAAR, D.J. \& TIMMERMANS, W. 2010. The Green Credit Tool report. (Value Added Planning, Volume 1). Part of the VALUE project (Valuing Attractive Landscapes in the Urban Economy, made possible by INTERREG IVB North West Europe, European Regional Development Fund, European Territorial Cooperation, 2007-2013. Wageningen UR, Van Hall Larenstein. 24p.

CILliERS, E.J., DIEMONT, E., STOBBELAAR, D.J. \& TIMMERMANS, W. 2010. The Workbench Method report. (Value Added Planning, Volume 2). Part of the VALUE project (Valuing Attractive Landscapes in the Urban Economy, made possible by INTERREG IVB North West Europe, European Regional Development Fund, European Territorial Cooperation, 2007-2013. Wageningen UR, Van Hall Larenstein.

CILLIERS, E.J., DIEMONT, E., STOBBELAAR, D.J. \& TIMMERMANS, W. 2011. The Value Added Planning report. (Value Added Planning, Volume 3). Part of the VALUE project (Valuing Attractive Landscapes in the Urban Economy, made possible by INTERREG IVB North West Europe, European Regional Development Fund, European Territorial Cooperation, 2007-2013. Wageningen UR, Van Hall Larenstein. 55p.

\section{ARTIKELEN, NOG NIET GEPUBLICEERD}

CILLIERS, E.J. \& TIMMERMANS, W. 2012. Approaching Value Added Planning in the Green Environment. In Journal of Place Management and Development. ISSN: 1753-8335.

CILLIERS, E.J. \& TIMMERMANS, W. 2012. Value Added Planning: Planning beyond Development. In Journal of Development Studies. 
HET PLANNINGSPROCES MOET CENTRAAL STAAN, NIET DE DIRECTE OPBRENGSTEN VAN DAT PROCES. DAT WAS DE BELANGRIJKSTE CONCLUSIE DIE DE GEMEENTE AMERSFOORT TROK TEN AANZIEN VAN DE INZET VAN VALUE AdDED PLANNING. DIRECTE, ECONOMISCHE OPBRENGSTEN VAN GROENE INFRASTRUCTUUR ZIJN MOEILIJK TE BEREKENEN, MAAR ER IS WEL MEERWAARDE MOGELIJK DOOR VANAF HET BEGIN VAN DE PLANVORMING VERSCHILLENDE DISCIPLINES TE LATEN SAMENWERIEN 。 

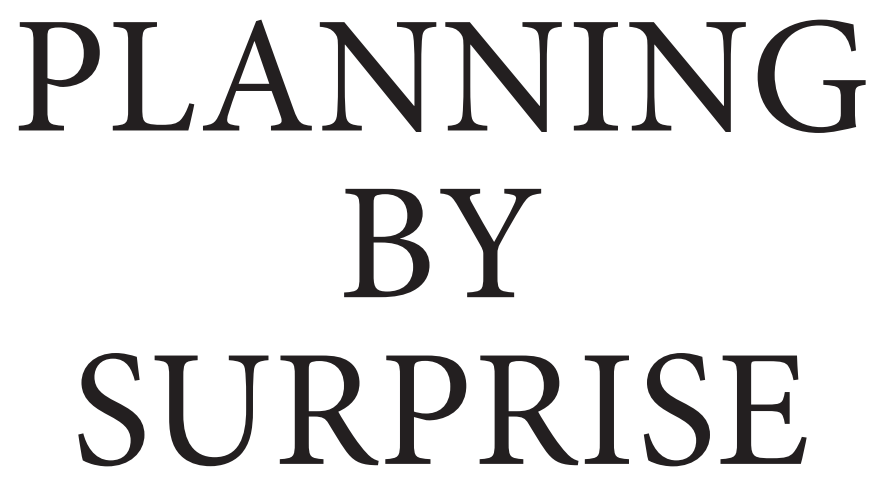

de beelden van de groene stad

Foto merge

Jos Jonkhof 


DE LEVENDIGE GROENE STAD ZOALS DIE WEL BEDOELD IS,

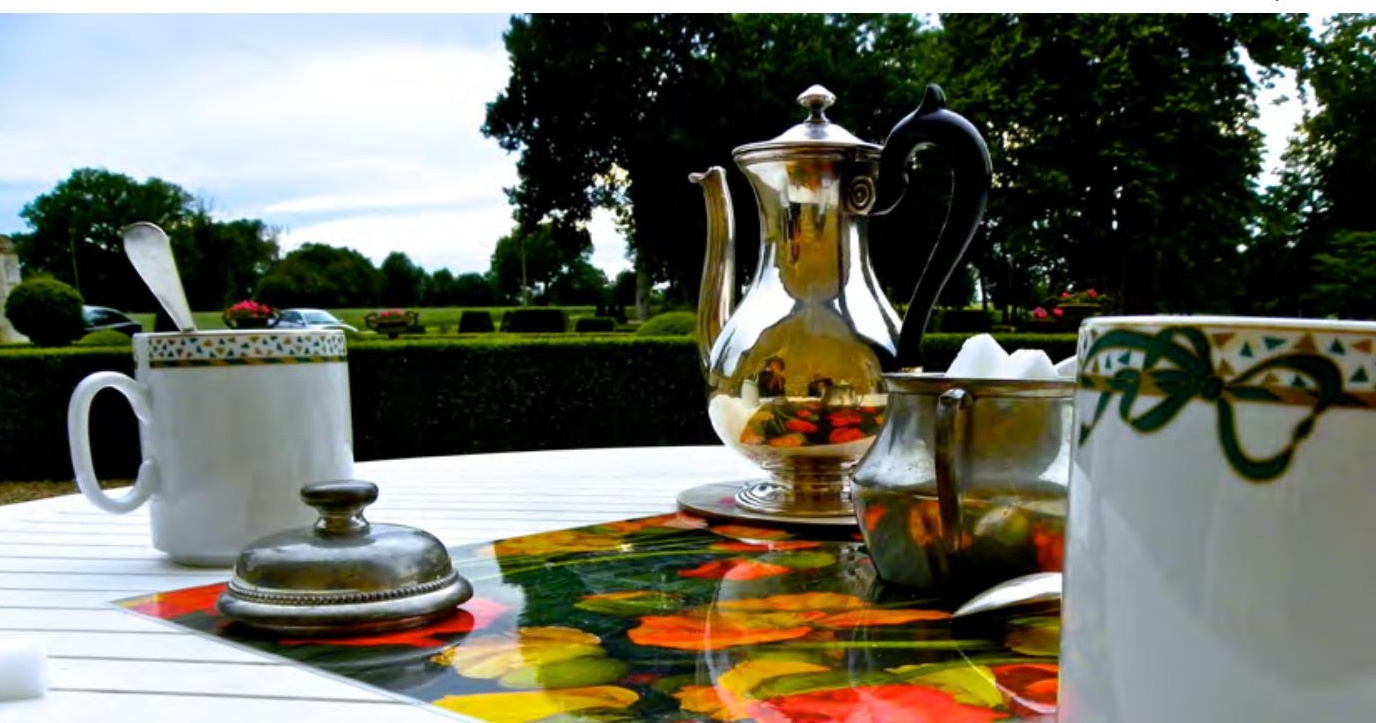



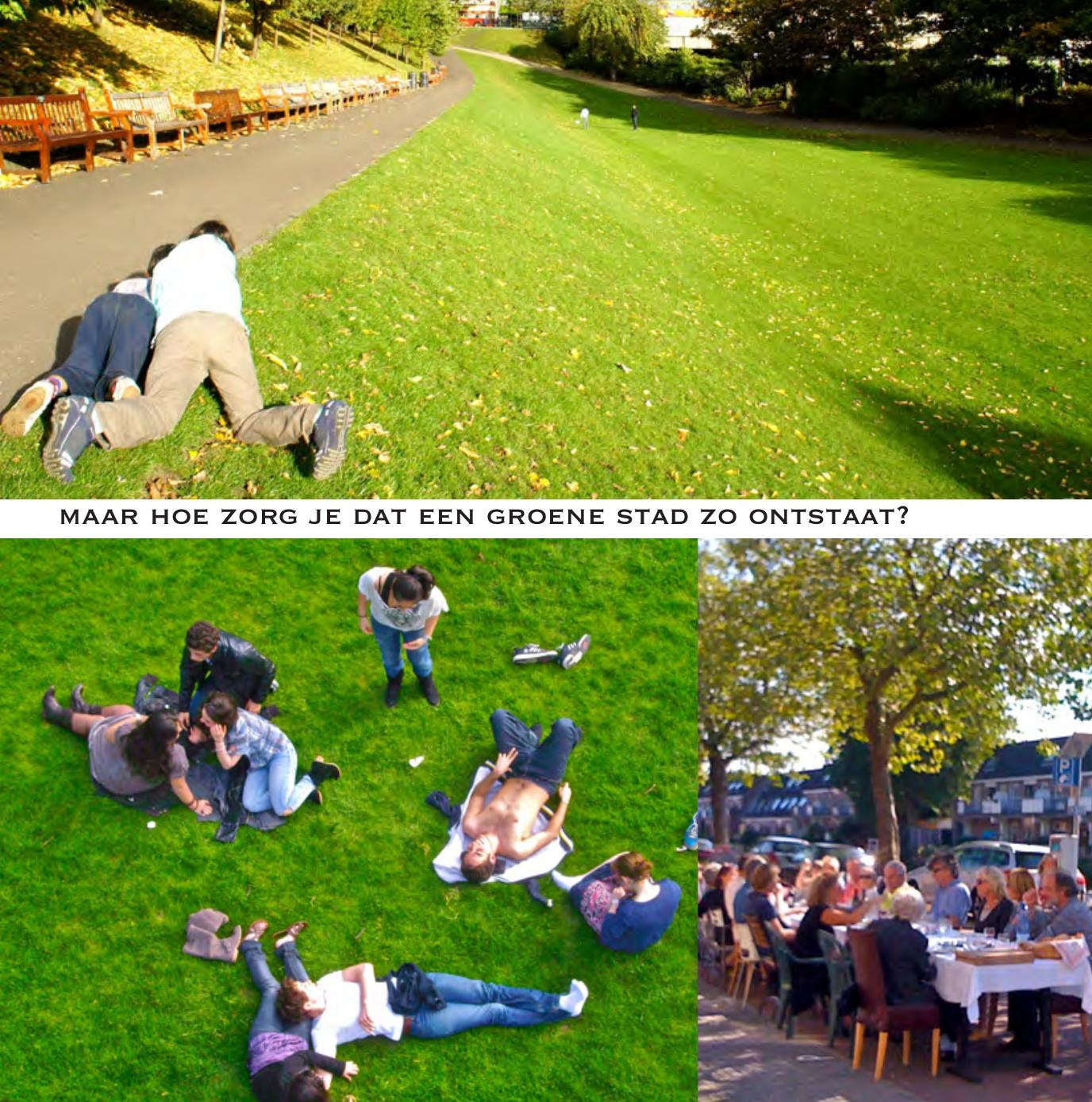

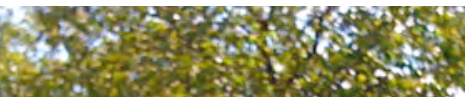

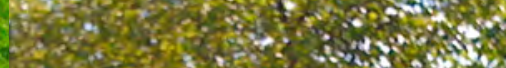

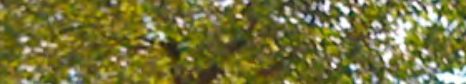

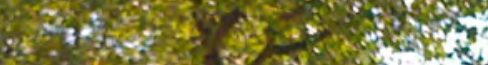

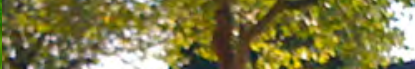

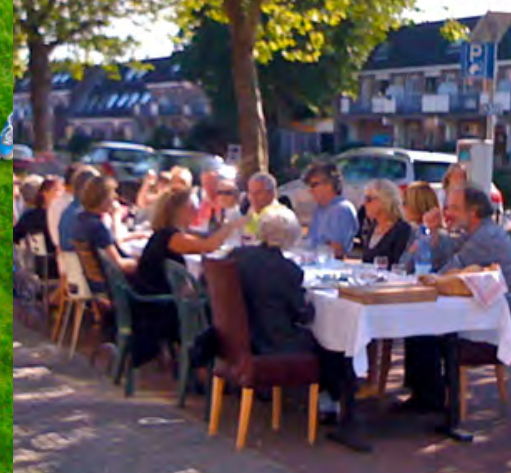




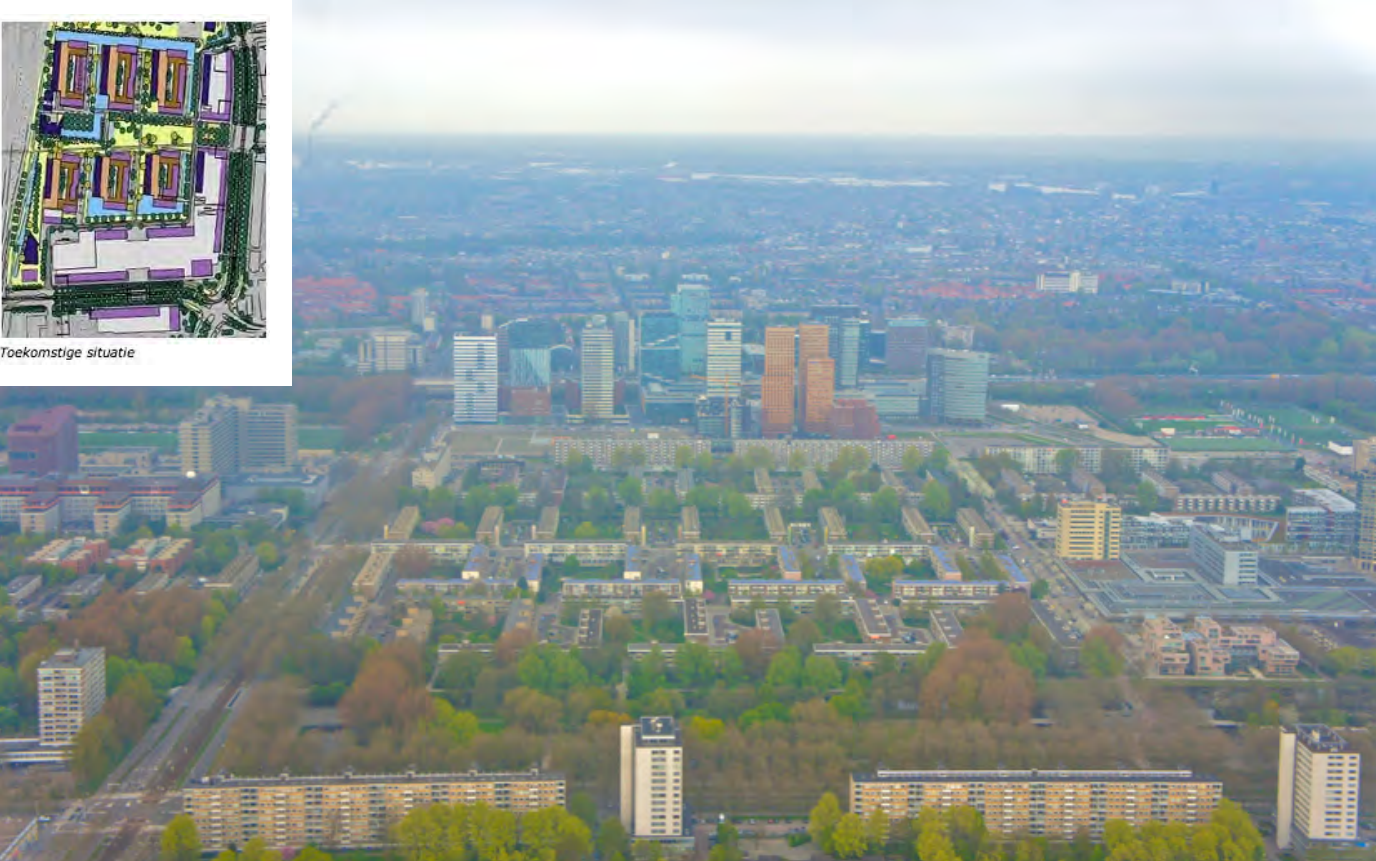




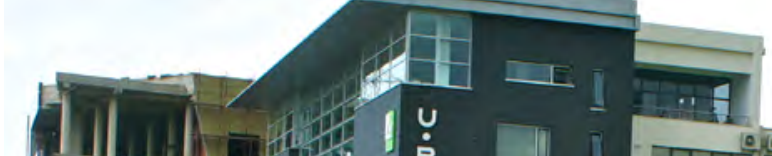

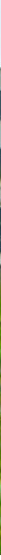

MAAR NIEMAND DIE DAAR IETS VAN ZIET

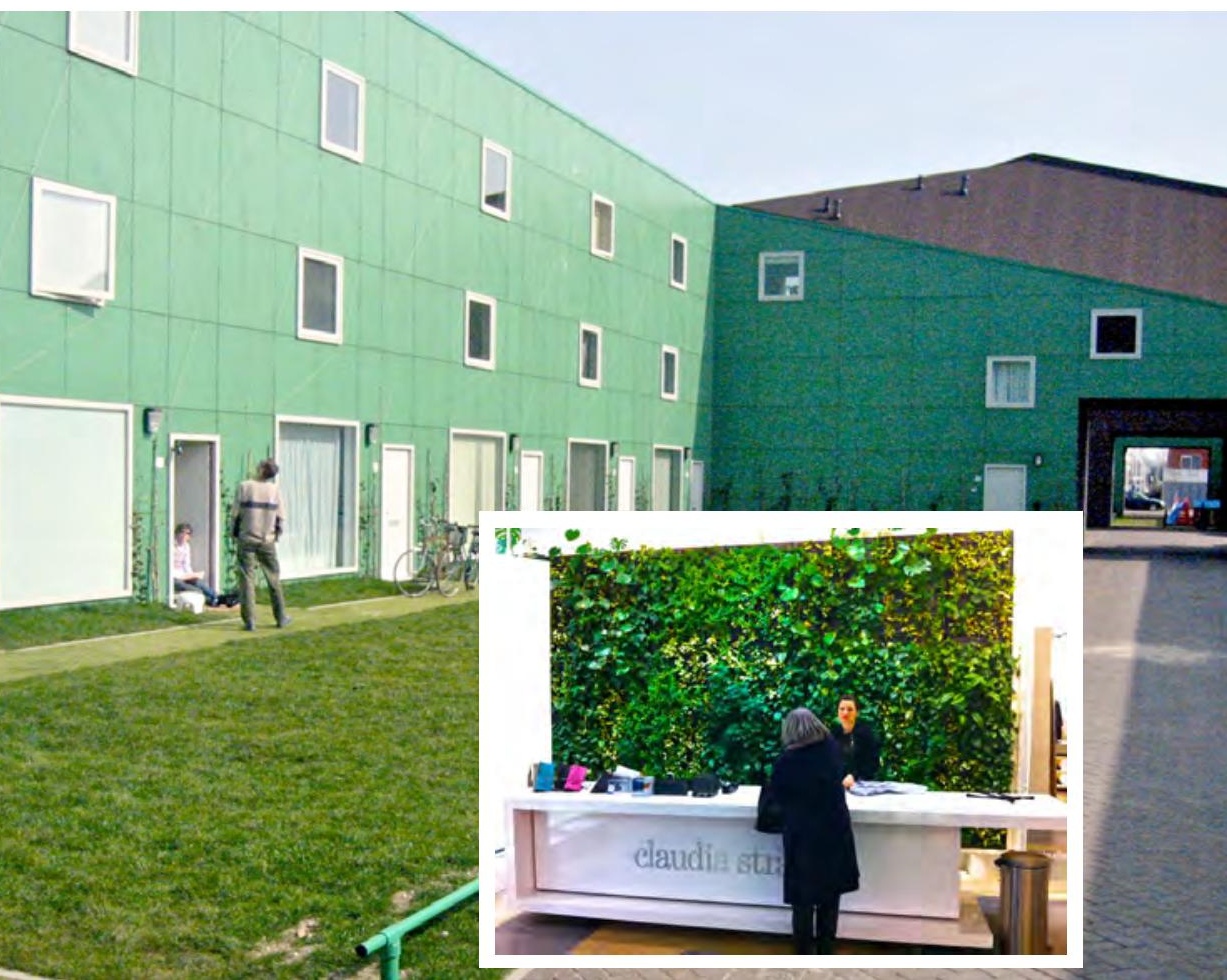




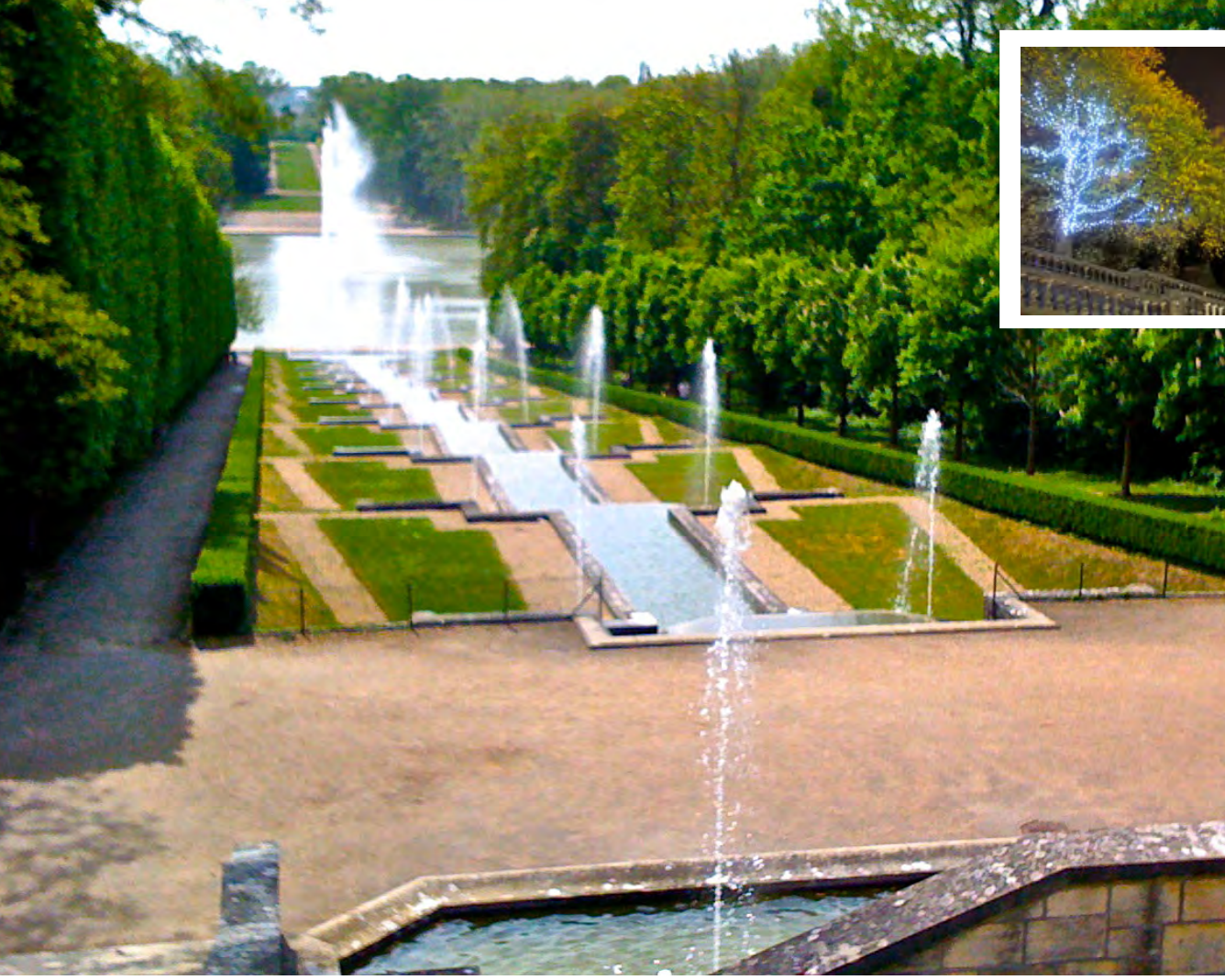

DE GROENE STAD IS GEEN PLAN DAT GESCHIEDENIS WORDT,
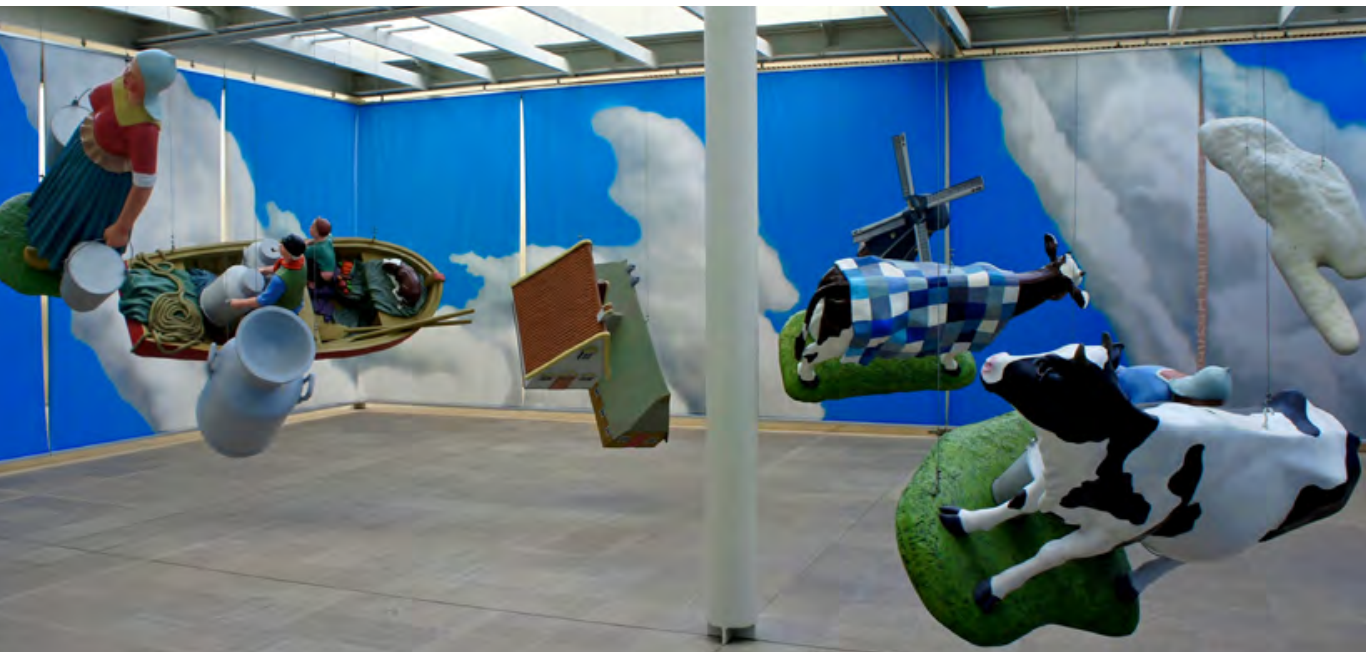


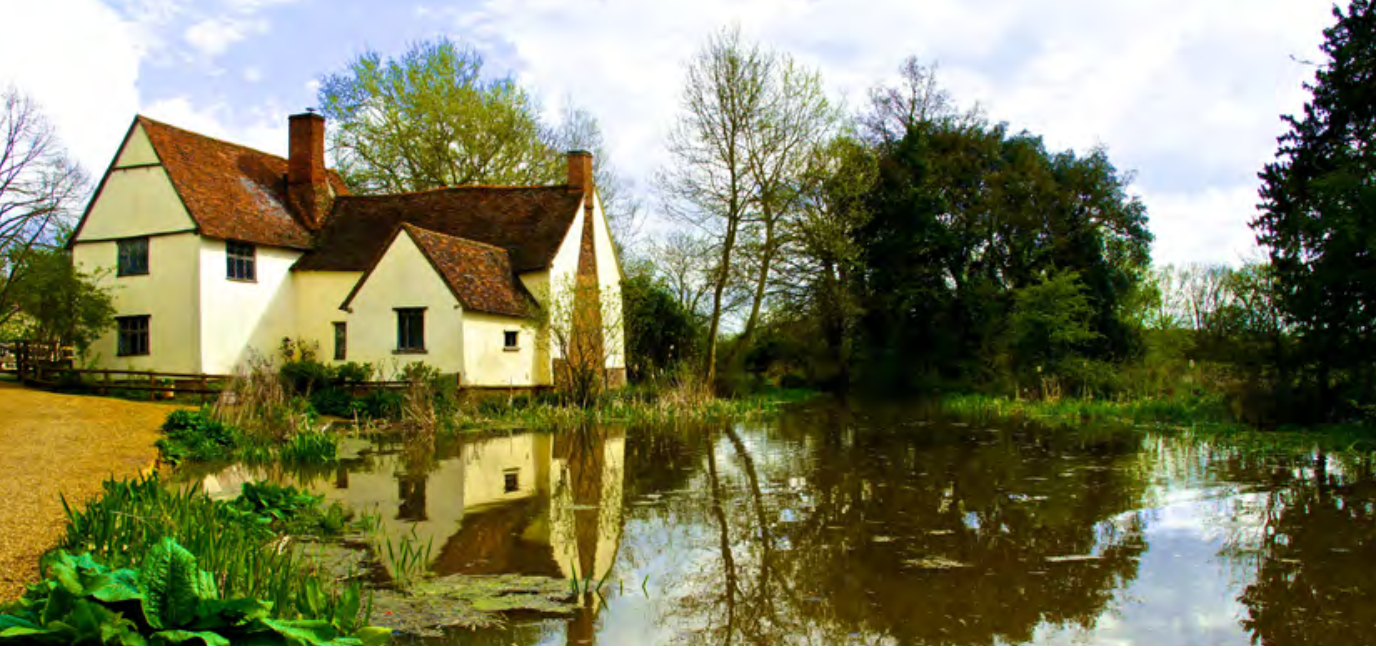

\section{DE GROENE STAD IS GEDROOMD, VERBEELD, VERTAALD,}

N 1 .
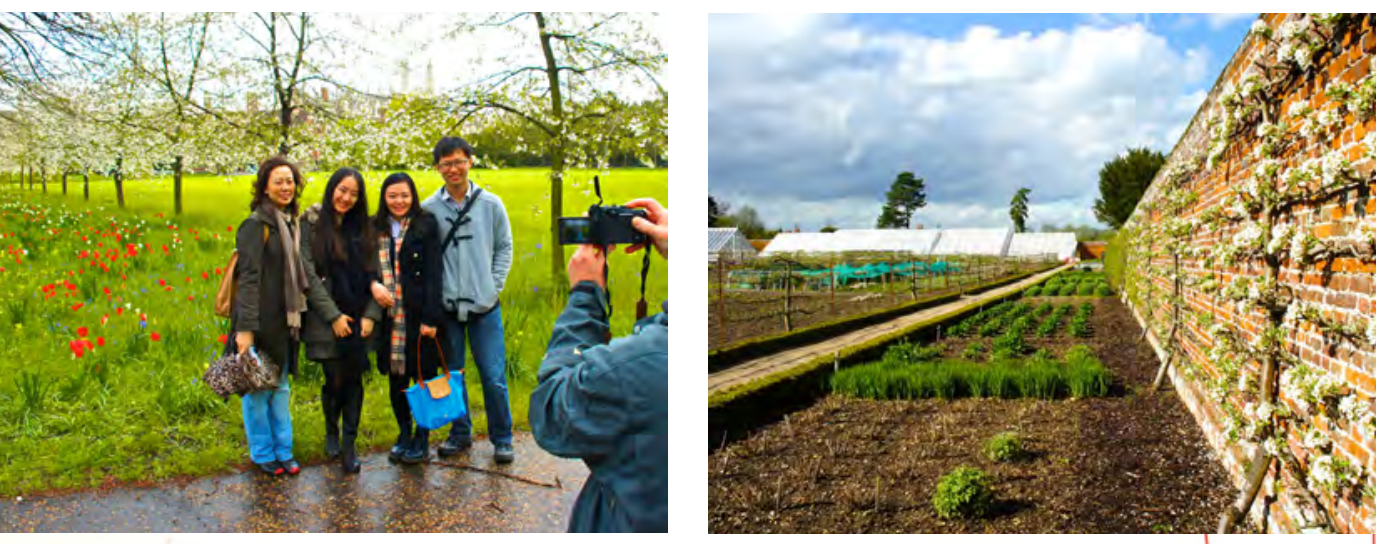

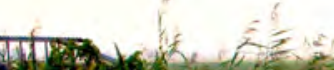

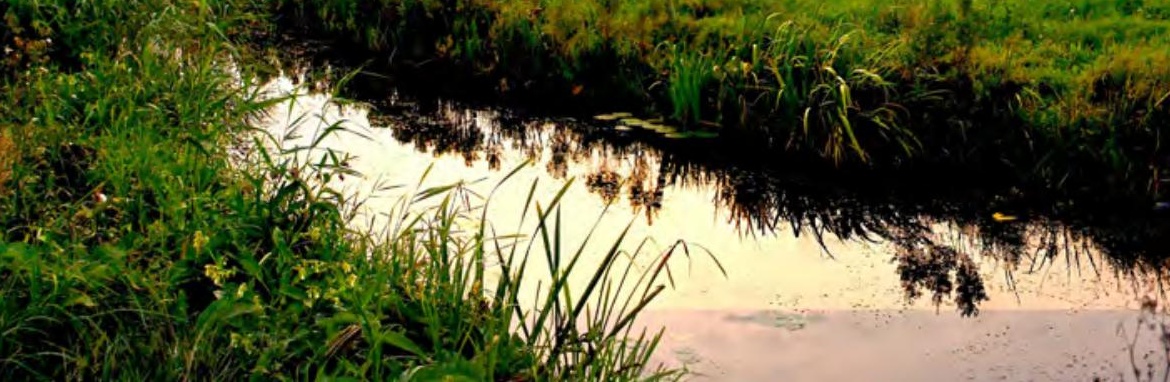




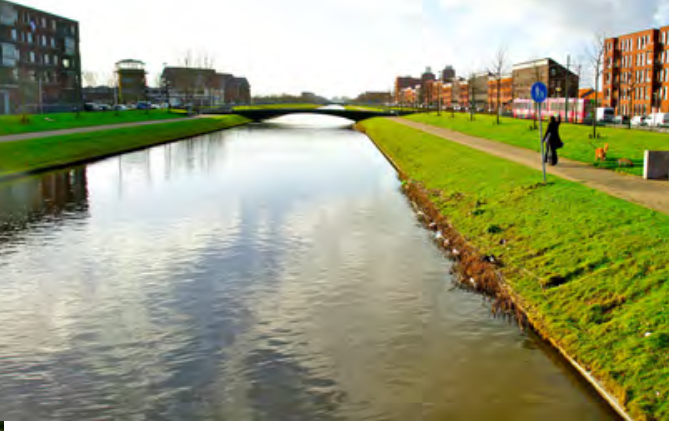

GESCHREVEN, VERGETEN, WEER OPNIEUW ONTDEKT
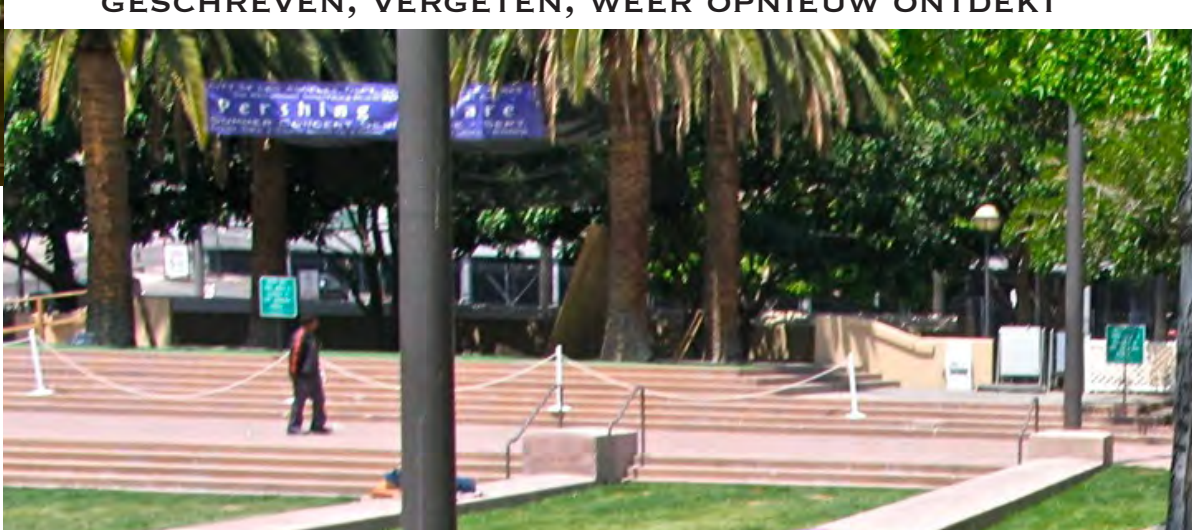

1. E

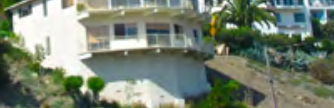
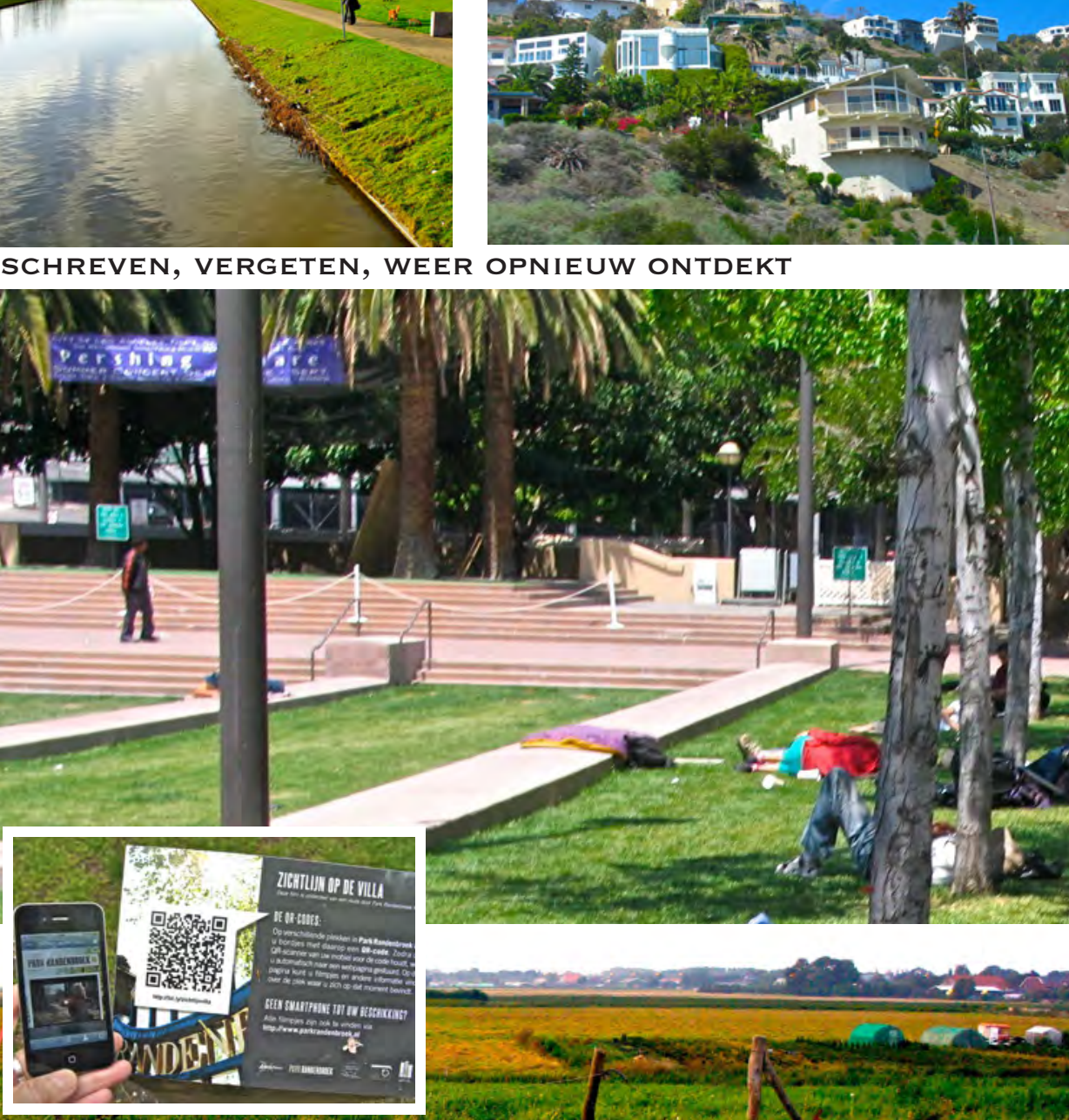

1 
